\title{
Cyclic changes in the circulating and urinary levels of ovarian steroids in the adult female owl monkey (Aotus trivirgatus)
}

\author{
Rosemary C. Bonney, A. F. Dixson and D. Fleming \\ Wellcome Laboratories of Comparative Physiology, Institute of Zoology, Zoological Society of \\ London, Regent's Park, London NWI 4RY, U.K.
}

\begin{abstract}
Summary. Circulating levels of oestrone and progesterone were measured by radioimmunoassays in plasma samples from 5 female owl monkeys on 60 consecutive days. Both steroids exhibited cyclic fluctuations and based on nadir to nadir intervals the ovarian cycle was estimated to be $15.92 \pm 0.26$ days. Levels of oestrone and pregnanediol-3 $\alpha$-glucuronide were also measured in daily urine samples. The fluctuations of urinary steroids reflected those observed in plasma. Ketamine sedation had no effect on the length of the cycle. Peak values of plasma progesterone and oestrone were $250.48 \pm 11.37$ and $3.59 \pm 0.066 \mathrm{ng} / \mathrm{ml}$ respectively.

There was no clear hormonal distinction between the follicular and luteal phase of the cycle in these owl monkeys.
\end{abstract}

\section{Introduction}

The owl monkey (Aotus trivirgatus) has in recent years become an important laboratory model for research on human malaria (Geiman \& Meagher, 1967; Voller, Green \& Richards, 1973; Hayes \& Ward, 1977; Schmidt, 1978) and the viral induction of cancer (Baharona, Melendez, Hunt \& Daniel, 1976; Epstein, 1976; Hunt, Baharona \& Daniel, 1978). Limitations on the export of Aotus from South America make the establishment of captive breeding programmes a matter of great importance. The limited information available about the reproductive biology of the owl monkey (Elliott, Sehgal \& Chalifoux, 1976; Cicmanec \& Campbell, 1977; Meritt, 1977) does not include data relating to its reproductive endocrinology. Indeed, there have been few reports of hormonal studies of reproductive cycles of New World monkeys in general. Work to date has been restricted to the common marmoset (Hearn \& Lunn, 1975; Hearn, Abbott, Chambers, Hodges \& Lunn, 1978), tamarins (Preslock, Hampton \& Hampton, 1973) and the squirrel monkey (Wolf, O'Connor \& Robinson, 1977).

We therefore undertook the present study to determine the pattern of cyclicity of circulating and urinary levels of ovarian steroids in owl monkeys.

\section{Materials and Methods}

\section{Experimental animals}

Six adult female owl monkeys of Colombian origin, weighing $800-1000 \mathrm{~g}$, were housed in individual cages under conditions of controlled temperature $\left(20-25^{\circ} \mathrm{C}\right)$ and lighting (artificial light 02:00-14:00 h, dim red light 14:00-02:00 h). The cages (approximately $102 \times 55 \times 66$ $\mathrm{cm}$ ) were fitted with removable sloping trays and funnels in the base for urine collections, and with a nest box for trapping animals for tranquillization. 
The animals were fed daily with pelleted diet (Mazuri), cereal (Farex), fruit (apple, orange, grape, banana, dates), vegetables (lettuce, carrot, tomato) and seeds (sunflower, ground nut). Locusts, mice and mealworms were provided regularly, and water was always available.

An iron preparation (Jectofer: Astra Chemicals Ltd, Watford, Herts, U.K.) was administered $(0.15 \mathrm{mg}$ i.m.) to each animal at weekly intervals throughout the duration of blood sampling. Blood haematocrit levels were monitored weekly and maintained by supplementary i.m. administration of vitamin $B_{12}(75 \mu \mathrm{g}$ Cyanocobalamin: C-Vet Ltd, Braintree, Essex, U.K.) and oral administration of folic acid $(175 \mu \mathrm{g})$ and ferrous sulphate $(150 \mathrm{mg})$ obtained in tablet form (Ferrograd Folic: Abbott Laboratories Ltd, Queenborough, Kent, U.K.). The animals remained in good health throughout the period of blood sampling and loss of body weight was minimal.

\section{Collection of samples}

Blood. Of the 6 animals selected for the study, 5 were trained to enter the nest box for a food reward. When training was complete (after about 2 weeks) each female was tranquillized daily between 10:00 and 13:00 h for 60 days by i.m. injection of 10 mg ketamine $\mathrm{HCl}$ (Ketalar: Parke Davis, Pontypool, Gwent, U.K.). Blood $(1 \mathrm{ml})$ was withdrawn from the femoral vein with a heparinized syringe and centrifuged immediately. The plasma was stored at $-20^{\circ} \mathrm{C}$ for subsequent analysis.

Urine. Urine samples, which represented approximately 24 -h collections, were obtained each morning at 09:00-10:00 $\mathrm{h}$ from all 6 females. This group therefore included 1 animal which had not been subjected to ketamine sedation and could therefore serve as a control for the effects of the blood sampling procedure on the length of the oestrous cycle. Collections were made via the funnel at the base of the cage into a vessel containing $0.5 \mathrm{ml}$ sodium azide (1\%). Trays and funnels were washed daily between sample collections. Each sample was checked for the presence of menstrual blood with the aid of Hemastix (Ames Co.) before storage at $-20^{\circ} \mathrm{C}$ for analysis.

Analyses. Preliminary investigations using specific radioimmunoassays indicated that the ratio of oestrone to oestradiol in owl monkey plasma was approximately $5: 1$ (R. C. Bonney, unpublished observations). Similar proportions of these two oestrogens, as determined both by radioimmunoassay and by gas chromatography -mass spectrometry $(R$. C. Bonney \& K. D. R. Setchell, unpublished), were present in urine. The oestrogen of choice for a study of hormonal cyclicity was therefore oestrone.

Gas chromatography-mass spectrometry studies have shown that, like the marmoset (Shackleton, 1974, 1975), the owl monkey excretes progesterone mainly as 6 $\beta$-hydroxypregnanolone, but that $16 \alpha$-hydroxypregnanolone and pregnanediol are also important metabolites (R. C. Bonney \& K. D. R. Setchell, unpublished). The availability of a radioimmunoassay for pregnanediol-3 $\alpha$-glucuronide thus presented a simple means of estimating the excretion of progesterone throughout the cycle. Urine samples were similarly assayed for oestrone and pregnanediol-3 $\alpha$-glucuronide and hormone levels related to urinary creatinine concentrations, as determined by the method of Slott (1965).

\section{Radioimmunoassay of steroids}

Urinary oestrone. An aliquot of each urine sample $(50 \mu \mathrm{l})$ was hydrolysed with $0.4 \mathrm{i} . \mathrm{u}$. $\beta$ glucuronidase 'Pasteur' (Uniscience) in $50 \mu$ phosphate-buffered saline $(0.02 \mathrm{M}$ phosphate buffer, $\mathrm{pH} 7.0$, containing $0.2 \% \mathrm{NaCl}$ and $0.02 \% \mathrm{NaN}_{3}$ ) for $1 \mathrm{~h}$ at $37^{\circ} \mathrm{C}$. Each hydrolysed urine sample was then diluted with an appropriate volume (usually 1:10000) of Tris-buffered saline $\left(0.05 \mathrm{M}\right.$-Tris- $\mathrm{HCl}$ buffer, $\mathrm{pH} 8.0$, containing $0.1 \mathrm{M}-\mathrm{NaCl}, 0.1 \% \mathrm{NaN}_{3}$ and $0.1 \%$ gelatin) before direct radioimmunoassay without extraction or chromatography. 
Samples were assayed in duplicate in $12 \times 75 \mathrm{~mm}$ glass tubes using an antiserum (Searle Diagnostic, High Wycombe, Bucks, U.K.) raised in a rabbit to oestrone-6-(O-carboxymethyl)oxime-bovine serum albumin. The cross-reactivities for other oestrogens were: oestradiol-17 $\beta$, 1.6\%; oestradiol-17a, 1.5\%; and oestriol, $0.01 \%$. Each assay tube contained $100 \mu$ diluted hydrolysed urine, $100 \mu \mathrm{l}(\sim 60 \mathrm{pg})\left[2,4,6,7(\mathrm{n}){ }^{3} \mathrm{H}\right]$ oestrone (sp. act. $110 \mathrm{Ci} / \mathrm{mmol}$ : Radiochemical Centre, Amersham, U.K.) and $100 \mu$ antiserum diluted to give approximately $32 \%$ binding of $\left[{ }^{3} \mathrm{H}\right]$ oestrone in the absence of unlabelled steroid. Each tube was briefly mixed and incubated for $1 \mathrm{~h}$ at $37^{\circ} \mathrm{C}$ followed by $30 \mathrm{~min}$ at $4^{\circ} \mathrm{C}$. Separation of antibody-bound and free steroid was achieved by the addition of $200 \mu \mathrm{l}$ dextran-coated charcoal suspension $(1.0 \%$ charcoal, Sigma; $0.1 \%$ dextran T-70, Pharmacia, in assay buffer). The incubation period ( $3 \mathrm{~min}$ at $4^{\circ} \mathrm{C}$ ) was followed by centrifugation for $4 \mathrm{~min}$ at $1500 \mathrm{~g}$. Supernatant $(300 \mu \mathrm{l})$ was removed to a mini-scintillation vial containing $4 \mathrm{ml}$ scintillant (prepared from 21 toluene (LR), 11 Triton $\mathrm{X}-100,12 \mathrm{~g}$ PPO and $1.2 \mathrm{~g}$ dimethyl POPOP and counted for $10 \mathrm{~min}$ in a Packard Tri-Carb liquid scintillation spectrometer (Model 3003). A standard curve ranging from 0.078 to $1.0 \mathrm{ng}$ per tube was processed similarly for each set of samples analysed. The $50 \%$ level of inhibition occurred at $0.126 \pm 0.003$ (s.e.m.) ng per tube $(n=17)$.

Intra- and inter-assay coefficients of variation $(n=10)$ were $9.2 \%$ and $10 \cdot 5 \%$ respectively, as established by repeated assay of a hydrolysed urine pool in a single assay and in separate assays. Accuracy was determined by the measurement of added known amounts of oestrone $(0.5,0.25,0.125,0.0625,0.0313 \mathrm{ng} /$ tube $)$ to hydrolysed urine from a castrated male animal (diluted 1:10000). A linear regression was found for estimated oestrone against added oestrone $(y=1.075 x-0.017)$, the slope of which was not significantly different from the expected value of 1 .

Plasma oestrone. Duplicate aliquots of plasma $(50 \mu \mathrm{l})$ were extracted with $1.0 \mathrm{ml}$ freshly distilled diethyl ether (BDH 'AnalaR': Poole, Dorset, U.K.) by shaking on a vortex mixer for 30 sec. The aqueous layer was then frozen in an acetone $/ \mathrm{CO}_{2}$ bath, the organic phase decanted into $12 \times 75 \mathrm{~mm}$ glass assay tubes and evaporated to dryness. The dried extracts were redissolved in $100 \mu \mathrm{l}$ Tris-buffered saline and assayed without chromatography by the procedure described above.

All samples were corrected for buffer blanks $(0.016 \pm 0.0016 \mathrm{ng}, n=17)$ and procedural losses as determined in each assay by recovery of $\left[{ }^{3} \mathrm{H}\right]$ oestrone added to a pool of plasma $(83.4$ $\pm 5 \cdot 6 \%, n=48$ ).

Inter- and intra-assay coefficients of variation, calculated to be $9.8 \%(n=9)$ and $7.6 \%(n=8)$ respectively, were evaluated by duplicate estimations of a plasma pool in a single assay and in separate assays. Accuracy was determined by the addition of known amounts of oestrone $(0.5$, $0.25,0.125,0.0625,0.0313 \mathrm{ng})$ to male plasma which had been extracted twice with 10 volumes diethyl ether to remove endogenous oestrone. A linear regression was found for estimated oestrone against added oestrone $(y=1.001 x+0.016)$, the slope of which was not significantly different from the expected value of 1 .

Plasma progesterone. Plasma progesterone levels were determined using an antiserum $(465 / 6)$ raised in a goat to progesterone-11 $\alpha$-succinyl-bovine serum albumin, kindly donated by Dr B. J. A. Furr (ICI Pharmaceuticals Ltd, Macclesfield, Cheshire, U.K.). Cross-reactivity with the majority of $\mathrm{C} 18$ and $\mathrm{C} 19$ steroids tested was less than $0.1 \%$. Of the $\mathrm{C} 21$ steroids tested, $5 \alpha$ and $5 \beta$-pregnane-3,20-dione cross-reacted significantly $(35.3$ and $2.5 \%$ respectively), as did $11 \alpha$ - and $11 \beta$-hydroxypregn-4-ene-3,20-dione (177.0 and $35 \%$ respectively) but the extraction procedure adopted in the assay eliminated possible interference by these last two steroids (B. J. A. Furr, personal communication).

An aliquot $(20 \mu \mathrm{l})$ of each plasma sample was diluted to $1.0 \mathrm{ml}$ with phosphate buffer $(0.1$ M-phosphate, $\mathrm{pH} 7.0$, containing $0.1 \% \mathrm{NaN}_{3}$ and $0.1 \%$ gelatin). Duplicate volumes $(0.1 \mathrm{ml})$ of diluted plasma were then extracted for $30 \mathrm{sec}$ with $1.0 \mathrm{ml}$ freshly distilled light petroleum ether (b.p. $40-60^{\circ} \mathrm{C}, \mathrm{BDH}$ 'AnalaR' grade). The organic layer was separated and decanted into $12 \times$ 
$75 \mathrm{~mm}$ glass assay tubes containing $50 \mu \mathrm{l}(\sim 90 \mathrm{pg})\left[1,2,6,7(\mathrm{n}){ }^{3} \mathrm{H}\right]$ progesterone (sp. act. 85 $\mathrm{Ci} / \mathrm{mmol}$ : Radiochemical Centre). The combined solvents were evaporated to dryness under a stream of nitrogen in a water bath at $45^{\circ} \mathrm{C}$. Standards within the range 0.009 to $5 \mathrm{ng}$ per tube, prepared in $50 \mu \mathrm{l}$ toluene, were added to tubes containing $50 \mu \mathrm{l}\left[{ }^{3} \mathrm{H}\right]$ progesterone and evaporated together with the sample extracts. Dried residues were then redissolved in $300 \mu \mathrm{l}$ antiserum, diluted with phosphate buffer to give approximately $30 \%$ binding of $\left[{ }^{3} \mathrm{H}\right]$ progesterone in the absence of unlabelled steroid, and incubated overnight at $4{ }^{\circ} \mathrm{C}$. Separation of bound and free steroid was accomplished with dextran-coated charcoal as described above, using a suspension of $1.0 \%$ charcoal and $0.15 \%$ dextran T-70 in phosphate buffer, $\mathrm{pH} 7.0$. All samples were corrected for buffer blanks $(0.0188 \pm 0.0027 \mathrm{ng}, n=14)$ and procedural losses as determined in each assay by the recovery of $\left[{ }^{3} \mathrm{H}\right]$ progesterone added to a pool of plasma diluted $1: 40(83.22$ $\pm 1 \cdot 08, n=60)$. The $50 \%$ level of inhibition occurred at $0.159 \pm 0.0069 \mathrm{ng}(n=11)$.

Accuracy of the assay was determined by the recovery of known amounts of progesterone $(0.5,0.25,0.125,0.0625 \mathrm{ng})$ added to plasma from a castrated male (diluted $1: 40)$. The slope of the regression line $(y=0.89 x-0.007)$ for estimated progesterone against added progesterone was not significantly different from 1 .

A pool of plasma assayed in a single assay and in separate assays $(n=10)$ gave intra- and inter-assay coefficients of variation of $7 \cdot 3$ and $14 \cdot 17 \%$ respectively.

Urinary pregnanediol-3- $\alpha$-glucuronide. Urine samples were assayed for pregnanediol-3aglucuronide by using reagents supplied by the Courtauld Institute of Biochemistry, Middlesex Hospital Medical School, London, U.K. The materials included standard (5 $\beta$-pregnane-20 $\alpha$-ol$3 \alpha$-yl-glucuronide), radioligand ([6,7- $\left.{ }^{3} \mathrm{H}\right] 5 \beta$-pregnane-20 $\alpha$-ol-3 $\alpha$-yl-glucuronide, sp. act. $43 \mathrm{Ci} /$ $\mathrm{mmol}$ ) and antiserum raised in a rabbit to $5 \beta$-pregnane-20a-ol-3a-yl-glucuronide-bovine serum albumin. Of the steroid glucuronides and free steroids tested for cross-reactivity only $5 \beta$-preg-

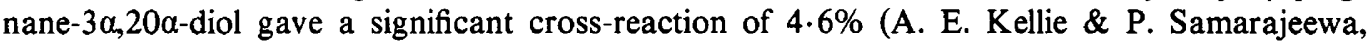
personal communication).

Each sample was diluted with an appropriate volume (usually 1:400) of phosphate-buffered saline $\left(0.1 \mathrm{~m}\right.$-phosphate, $\mathrm{pH} 7.0$, containing $0.9 \% \mathrm{NaCl}, 0.1 \% \mathrm{NaN}_{3}$ and $0.1 \%$ gelatin) to bring the steroid concentration into the working range of the standard curve $(0.0156$ to $4.0 \mathrm{ng}$ per tube, with a $50 \%$ level of inhibition at $0.45 \pm 0.0152 \mathrm{ng}, n=13$ ). The assay was carried out in $12 \times 75 \mathrm{~mm}$ siliconized glass tubes, each containing $100 \mu \mathrm{l}$ standard or diluted urine, 100 $\mu \mathrm{l}$ radioligand $(\sim 400 \mathrm{pg})$ and $100 \mu \mathrm{l}$ antiserum diluted to give approximately $40 \%$ binding in the absence of unlabelled steroid. Each tube was mixed briefly and incubated for $1 \mathrm{~h} \mathrm{at} 37^{\circ} \mathrm{C}$ followed by $30 \mathrm{~min}$ at $4^{\circ} \mathrm{C}$. Separation of bound and free steroid followed the procedure adopted for other assays in this study except that the charcoal suspension comprised $2.5 \%$ charcoal + $0.5 \%$ dextran $\mathrm{T}-70$ in $0.1 \mathrm{M}$-phosphate-buffered saline, $\mathrm{pH} \mathrm{7.0.} \mathrm{Intra-and} \mathrm{inter-assay} \mathrm{coefficients}$ of variation were $8.85 \%(n=11)$ and $17.2 \%(n=10)$ respectively, as determined by assay of a urine pool in a single assay and in separate assays.

Accuracy was determined by the measurement of known amounts of pregnanediol- $3 \alpha-$ glucuronide $(1,0.5,0.25 \mathrm{ng})$ added to urine from a castrated male $(1: 400)$. A linear regression was found for estimated pregnanediol-3a-glucuronide against the added steroid $(y=0.965 x-$ $0.06)$ the slope of which was not significantly different from the expected value of 1 .

\section{Results}

Of the 5 animals used in the study of plasma hormones, 3 showed regular hormonal cyclicity throughout the sampling period, 1 showed irregular changes and was eliminated from the study, while 1 was acyclic. The 6th animal, which had been used only for urine collections, had regular cycles. In none of the 6 animals was there any evidence of menstruation. 
The composite hormonal pattern of plasma and urinary steroids is illustrated in Text-fig. 1. Plasma levels of oestrone and progesterone are representative of 8 complete cycles from the 3 animals showing regular cycles. Day 0 was taken as the point of each cycle at which oestrone reached its lowest value, and the progesterone data were also related to this point. A similar method was adopted for representation of data obtained for urinary levels of oestrone and pregnanediol-3 $\alpha$-glucuronide.
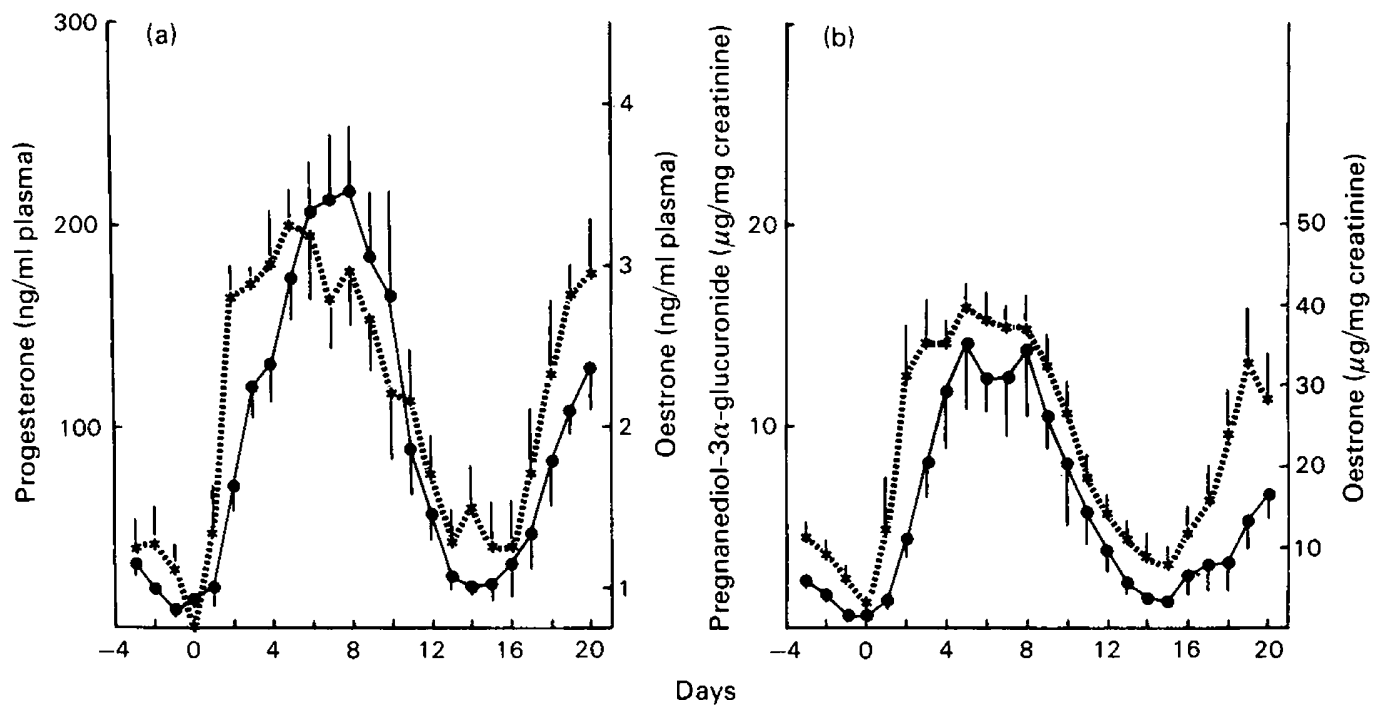

Text-fig. 1. Composite graph of cyclic changes in (a) plasma and (b) urinary levels of ovarian steroids in owl monkeys. Day 0 is the point of each cycle at which oestrone reaches its lowest value. (a) Mean \pm s.e.m. $(n=8$ cycles) peripheral plasma concentrations of oestrone $(\cdots \cdots)$ and progesterone $(-)$; (b) mean \pm s.e.m. $(n=11$ cycles) urinary levels of oestrone $(\cdots \cdots)$ and pregnanediol-3 $\alpha$-glucuronide $(\longrightarrow)$.

The cycle was characterized by a sharp increase in the level of circulating oestrone from Day 0 to reach a peak on Day 5. Plasma progesterone began to increase approximately $24 \mathrm{~h}$ after the initiation of the oestrone rise and attained a maximum level on Day 8, thereafter declining to basal values by Day 13 . Oestrone had similarly reached basal concentrations by Day 13 and remained low until the onset of the next cycle at Day 16.

The urinary metabolites of these hormones refiected the pattern obtained with plasma. Oestrone excretion increased rapidly from Day 0 to reach a peak on Day 5 . The rise in pregnanediol-3 $\alpha$-glucuronide began $24 \mathrm{~h}$ after the rise in oestrone to reach a peak on Day 8 although an earlier peak on Day 5 was also apparent.

Individual variation between animals is demonstrated by Text-fig. 2 which shows individual plasma and urinary levels of ovarian steroids throughout 2 cycles of 2 animals. There was a highly significant correlation $(P<0.001)$ between circulating levels of progesterone and the subsequent $24 \mathrm{~h}$ excretion of pregnanediol-3 $\alpha$-glucuronide (Monkey 5: $r=0 \cdot 71, n=58$; Monkey 6 : $r=0 \cdot 76, n=56$ ).

The highest and lowest values of the hormones measured are shown in Table 1. The length of the ovarian cycle ( \pm s.e.m.), based upon the time elapsed between successive plasma oestrone or progesterone troughs, was estimated to be $15.75 \pm 0.09$ and $15.38 \pm 0.22$ days respectively ( 8 complete cycles from 3 animals). Similar data were obtained for urinary oestrone $(16 \cdot 30 \pm 0.51$ days) and pregnanediol-3 $\alpha$-glucuronide (16.09 \pm 0.15 days) values in 11 complete cycles from 4 animals. The overall mean was $15.92 \pm 0.26$ days and the range was $13-19$ days with a median 

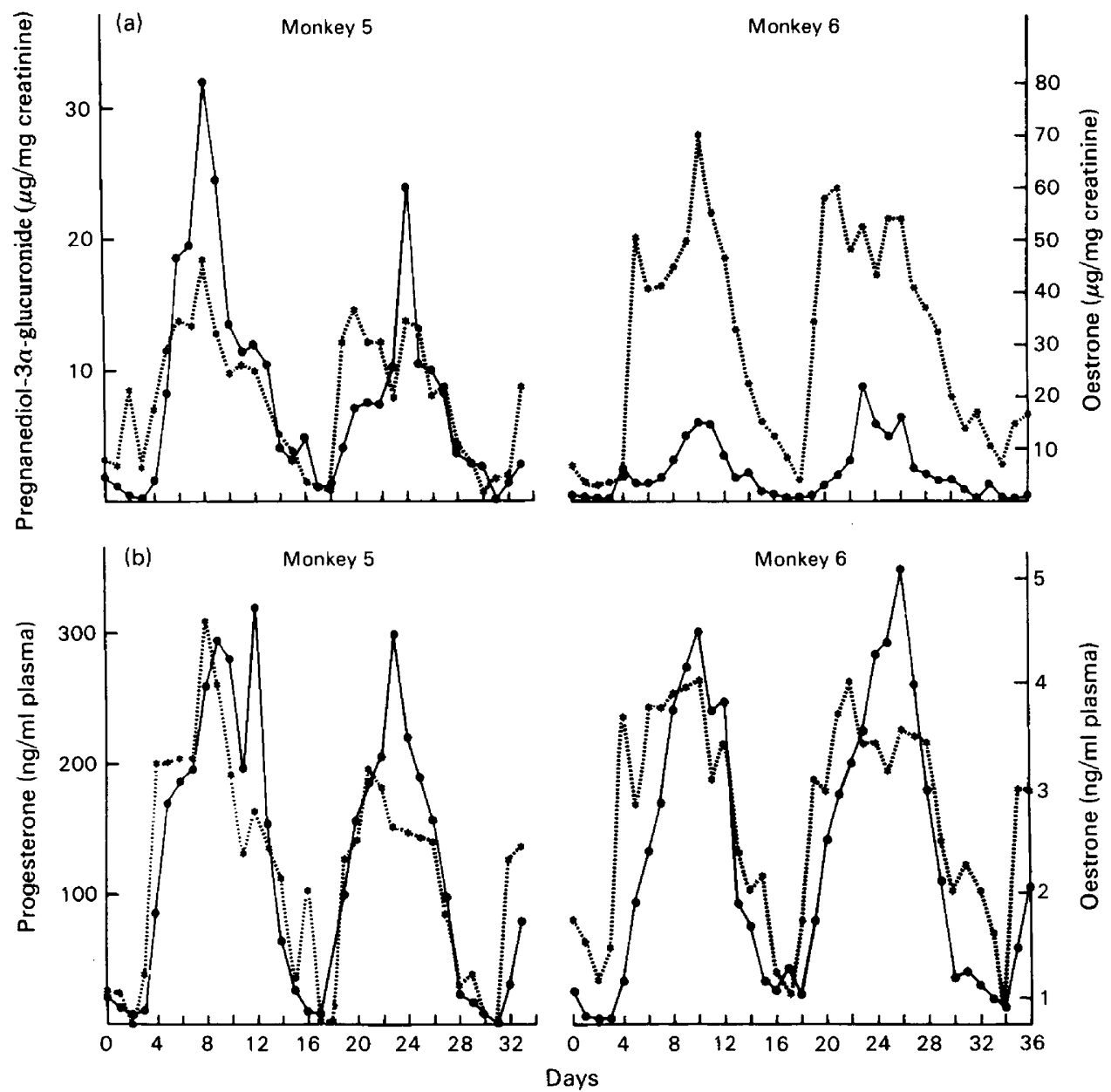

Text-fig. 2. Concentrations of ovarian steroids in (a) urine and (b) peripheral plasma through two successive cycles in Monkeys 5 and 6; Day $0=$ first day of sampling. (a) Urinary oestrone $(\cdots, \ldots)$ and pregnanediol-3a-glucuronide $(-)$; (b) plasma oestrone $(\cdots \cdots)$ and progesterone $(-)$.

Table 1. The highest and lowest values (mean \pm s.e.m., no. of observations in parentheses) of ovarian steroid hormones in plasma and urine of owl monkeys

\begin{tabular}{lrc}
\hline & \multicolumn{1}{c}{ Peak } & \multicolumn{1}{c}{ Nadir } \\
\hline Plasma $(\mathrm{ng} / \mathrm{ml})$ & & \\
$\quad$ Oestrone & $3.59 \pm 0.07(10)$ & $0.71 \pm 0.03(11)$ \\
Progesterone & $250.48 \pm 11.37(8)$ & $7.68 \pm 0.70(11)$ \\
Urine $(\mu \mathrm{m} / \mathrm{ml}$ creatinine) & & \\
$\quad$ Oestrone & $49.20 \pm 1.06(15)$ & $3.98 \pm 0.27(15)$ \\
$\quad$ Pregnanediol-3a-glucuronide & $19.84 \pm 0.83(15)$ & $0.39 \pm 0.02(15)$ \\
\hline
\end{tabular}

of 16 days. Daily urinary levels of oestrone and pregnanediol-3a-glucuronide in Monkey 2 throughout 2 consecutive cycles are shown in Text-fig. 3. Since this animal was used only for urine collections it served as a control for possible effects of the plasma sampling procedure. The mean cycle length for this animal ( $n=3$ cycles), based on oestrone levels, was $16.67 \pm 0.46$ 


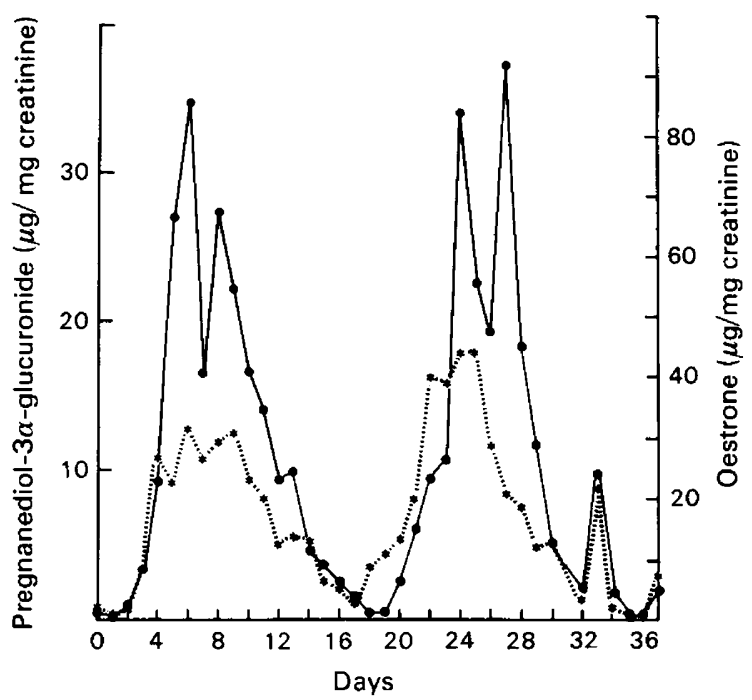

Text-fig. 3. Urinary levels of oestrone $(\cdots \cdots)$ and pregnanediol-3a-glucuronide $(\longrightarrow)$ through two successive cycles in Monkey 2 which was not sedated and bled. Day $0=$ first day of sampling.

days ( \pm s.e.m.) which was not significantly different $(t=1 \cdot 31$, d.f. 9) from the overall mean of $16.00 \pm 0.22$ days for the other 3 animals ( $n=8$ cycles).

The data shown in Text-fig. 4 are representative of the ovarian hormone profile of Monkey 4. The characteristic cyclicity observed in 4 other animals in this study was absent: maximum progesterone levels rarely exceeded $60 \mathrm{ng} / \mathrm{ml}$ while oestrone excretion was only occasionally in excess of $15 \mu \mathrm{g} / \mathrm{mg}$ creatinine.
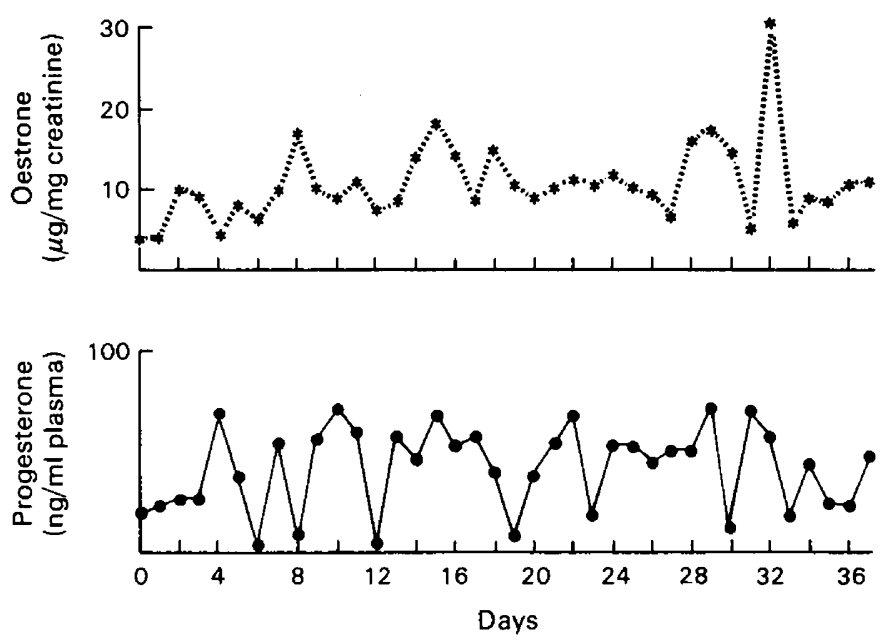

Text-fig. 4. Urinary excretion of oestrone and circulating levels of progesterone in Monkey 4 in which there was no obvious cyclicity.

\section{Discussion}

This study demonstrates that the owl monkey exhibits a cyclic variation in ovarian steroids of approximately 16 days which is much shorter than the average 28-day cycle characteristic of Old World monkeys, apes and women. However, New World monkeys in general appear to have 
shorter cycles (Table 2). There have been conflicting reports of the cycle length of the squirrel monkey but behavioural studies (Wilson, 1977) also indicate a cycle of 8-10 days, and unpublished hormonal data from our own laboratory support this conclusion.

In the New World species so far studied, the plasma levels of oestrogen and progesterone are 50-100 times greater than those reported for Old World species (Table 2). The ovaries of New World monkeys have been reported to contain an abundance of luteal tissue (Koering, 1974; Hertig, Barton \& Mackey, 1976) and such extensive and continuous luteinization of the ovary may well be responsible for the high levels of steroids observed.

Table 2. Mean \pm s.e.m. ovarian cycle length and peak levels of circulating oestrogens and progestagens among New World and Old World monkeys

\begin{tabular}{|c|c|c|c|c|}
\hline \multirow[b]{2}{*}{ Species } & \multirow{2}{*}{$\begin{array}{l}\text { Cycle length } \\
\text { (days) }\end{array}$} & \multicolumn{2}{|c|}{$\begin{array}{l}\text { Peak hormone levels } \\
\text { (ng/ml plasma) }\end{array}$} & \multirow[b]{2}{*}{ Reference } \\
\hline & & Oestrogen & Progestagen & \\
\hline \multicolumn{5}{|l|}{ New World } \\
\hline (Aotus trivirgatus) & $15.9 \pm 0.26$ & $3.6 \pm 0.06$ & $250.5 \pm 11.4$ & Present study \\
\hline $\begin{array}{l}\text { Common marmoset } \\
\text { (Callithrix jacchus) }\end{array}$ & $16 \cdot 4 \pm 1 \cdot 7$ & 0.8 to 2.0 & 140 & $\begin{array}{l}\text { Hearn et al. }(1978) \\
\text { Abbott \& Hearn } \\
\text { (1978) }\end{array}$ \\
\hline $\begin{array}{l}\text { Cotton topped tamarin } \\
\text { (Saguinus oedipus) } \\
\text { Red mantled tamarin } \\
\text { (Saguinus fuscicollis) }\end{array}$ & $15 \cdot 5 \pm 1 \cdot 5$ & $6.2 \pm 0.8$ & $272 \cdot 3 \pm 17 \cdot 5$ & Preslock et al. (1973) \\
\hline $\begin{array}{l}\text { Squirrel monkey } \\
\quad \text { (Saimiri sciureus) }\end{array}$ & $9.0 \pm 0.5$ & $0.5 \pm 0.06$ & $399 \cdot 5 \pm 27 \cdot 7$ & Wolf et al. (1977) \\
\hline \multicolumn{5}{|l|}{ Old World } \\
\hline $\begin{array}{l}\text { Rhesus monkey } \\
\text { (Macaca mulatta) }\end{array}$ & 28 & $0.35 \pm 0.05$ & $5.0 \pm 0.8$ & Knobil (1974) \\
\hline $\begin{array}{l}\text { Baboon } \\
\text { (Papio spp.) } \\
\text { Japanese monkey }\end{array}$ & $35 \cdot 3 \pm 0.76$ & 0.065 & $9 \cdot 13 \pm 1 \cdot 21$ & Wildt et al. (1977) \\
\hline (Macaca fuscata fuscata) & $28 \cdot 5 \pm 3 \cdot 0$ & - & $3 \cdot 8 \pm 2 \cdot 1$ & Oshima et al. (1977) \\
\hline (Macaca fascicularis) & 31 & - & 7.8 & $\begin{array}{l}\text { Stabenfeldt \& Hendrickx } \\
\text { (1973) }\end{array}$ \\
\hline
\end{tabular}

In the owl monkey there is not the clear hormonal distinction between the follicular and luteal phases of the cycle that is commonly present in Old World species, e.g. baboon (Koyama, de la Pena \& Hagino, 1977), cynomolgus monkey (Goodman, Descalzi, Johnson \& Hodgen, 1977), and rhesus monkey (Knobil, 1974). The squirrel monkey (Wolf et al., 1977) and the common marmoset (Hearn \& Lunn, 1975) do appear to have distinct follicular and luteal phases, but the tamarin is like the owl monkey in having oestrogen and progesterone profiles which are almost superimposed (Preslock et al., 1973). In the owl monkey the rise in oestrone usually precedes that of progesterone by approximately $24 \mathrm{~h}$. It is possible that there is more than one oestrogen peak in the cycle (Text-figs 2 and 3 ) and that it is the initial peak which triggers a postovulatory rise in progesterone or that oestradiol rather than oestrone is the biologically active oestrogen. Positive identification of a corpus lutem from interstitial tissue has not been possible. Hertig et al. (1976) suggested that both ovaries might function as a corpus luteum, luteinized interstitial tissue acting as thecal tissue and luteinized granulosa cell masses as luteal cells.

Although Monkey 4 (Text-fig. 4) was acyclic, wide fluctuations in progesterone levels were still observed (from 6 to $69 \mathrm{ng} / \mathrm{ml}$ ). In the owl monkey, therefore, the presence of very high levels of progesterone in the plasma are required to indicate that ovulation has occurred. The 
lack of effect of the sampling procedure on the cycle length of the owl monkey was not unexpected. Other workers have found that ketamine sedation is satisfactory for hormonal studies in primates (baboon: Koyama et al., 1977; rhesus monkey: Channing, Fowler, Engel \& Vitek, 1977)

This research was supported by grants from the Wellcome Trust (U.K.) to Dr R. D. Martin, from the World Health Organization to A.F.D. and the Royal Society to R.C.B. We also wish to thank Dr Martin for advice and encouragement, Mrs C. Tyler for skilled technical assistance, Mrs B. Murrill and the animal staff for care and maintenance of the animal colony and $\mathrm{Mr} \mathrm{T}$. B. Dennett for assistance in the preparation of the figures.

\section{References}

Abbott, D.H. \& Hearn, J.P. (1978) Physical, hormonal and behavioural aspects of sexual development in the marmoset monkey Callithrix jacchus. J. Reprod. Fert. 53, 155-166.

Baharona, H. Melendez, L.V., Hunt, R.D. \& Daniel, M.D. (1976) The owl monkey (Aotus trivirgatus) as an animal model for viral diseases and oncologic studies. Lab. Anim. Sci. 26, 1104-1112.

Channing, C.P., Fowler, S., Engel, B. \& Vitek, K. (1977) Failure of daily injections of ketamine $\mathrm{HCl}$ to adversely alter menstrual cycle length, blood estrogen and progesterone levels in the rhesus monkey (39862). Proc. Soc. exp. Biol. Med. 155, 615-619.

Cicmanec, J.C. \& Campbell, A.K. (1977) Breeding the owl monkey (Aotus trivirgatus) in a laboratory environment. Lab. Anim. Sci. 27, 512-517.

Elliott, M.E., Sehgal, P.K. \& Chalifoux, L.V. (1976) Management and breeding of Aotus trivirgatus. Lab. Anim. Sci. 26, 1037-1040.

Epstein, M.A. (1976) E.B. virus in the owl monkey (Aotus trivirgatus). Lab. Anim. Sci. 26, 1127-1130.

Geiman, Q.M. \& Meagher, M.J. (1967) Susceptibility of a New World monkey to Plasmodium falciparum from man. Nature, Lond. 215, 437.

Goodman, A.L., Descalzi, C.D., Johnson, D.K. \& Hodgen, G.D. (1977) Composite pattern of circulating $\mathrm{LH}, \mathrm{FSH}$, estradiol, and progesterone during the menstrual cycle in cynomolgus monkeys (39834). Proc. Soc. exp. Biol. Med. 155, 479-481.

Hayes, D.E. \& Ward, R.A. (1977) Sporozoite transmission of falciparum malaria (Burma-Thai strain) from man to Aotus monkey. Am. J. Trop. Med. Hyg. 26, 184-185.

Hearn, J.P. \& Lunn, S.F. (1975) The reproductive biology of the marmoset monkey (Callithrix jacchus). Lab. Anim. Handb. 6, 191-202.

Hearn, J.P., Abbott, D.H., Chambers, P.C., Hodges, J.K. \& Lunn, S.F. (1978) Use of the common marmoset (Callithrix jacchus) in reproductive research. Primate $M e d .10,40-49$.

Hertig, A.T., Barton, B.R. \& Mackey, J.J. (1976) The female genital tract of the owl monkey (Aotus trivirgatus) with special reference to the ovary. $L a b$. Anim. Sci. 26, 1041-1067.

Hunt, R.D., Baharona, H. \& Daniel, M.D. (1978) Herpes virus ateles malignant lymphoma in owl monkeys. In Advances in Comparative Leukemia Research, pp. 198-200. Eds P. Bentvelzen, J. Hilgers \& D. S. Yohn. Elsevier, Amsterdam.
Knobil, E. (1974) On the control of gonadotrophin secretion in the rhesus monkey. Recent Prog. Horm. Res. 30, 1-46.

Koering, M.J. (1974) Comparative morphology of the primate ovary. Contrib. Primat. 3, 38-81.

Koyama, T., de la Pena, A. \& Hagino, N. (1977) Plasma estrogen, progestin, and luteinizing hormone during the normal menstrual cycle in the baboon: role of luteinizing hormone. Am. J. Obstet. Gynec. 127, 67-72.

Merith, D.A., Jr (1977) Reproductive record of owl monkeys (Aotus trivirgatus) at Lincoln Park Zoological Gardens. Lab. Primate Newsl. 16, 11-12.

Oshima, K., Hayashi, M. \& Matsubayashi, K. (1977) Progesterone levels in the japanese monkey (Macaca fuscata fuscata) during the breeding and nonbreeding season and pregnancy. J. med. Primatol. 6, 99-107.

Preslock, J.P., Hampton, S.H. \& Hampton, J.K., Jr (1973) Cyclic variations of serum progestins and immuno-reactive estrogens in marmosets. Endocrinology 92, 1096-1101.

Schmidt, L.H. (1978) Plasmodium falciparum and Plasmodium vivax infections in the owl monkey (Aotus trivirgatus). I. The course of untreated infections. II. Responses to chloroquine, quinine and pyrimethamine. III. Methods employed in the search for new blood schizonticidal drugs. Am. J. Trop. Med. Hyg. 27, 671-737.

Shackleton, C.H.L. (1974) Progesterone and oestrogen metabolism in the pregnant marmoset (Callithrix jacchus). J. Steroid Biochem. 5, 597-600.

Shackleton, C.H.L. (1975) The excretion of steroids by the adult marmoset monkey (Callithrix jacchus). $J$. Steroid Biochem. 6, 1429-1432.

Slott, C. (1965) Plasma creatinine determination. A new and specific Jaffe reaction method. Scand. J. clin. Lab. Invest. 17, 381-387.

Stabenfeldt, G.H. \& Hendrickx, A.C. (1973) Progesterone studies in the Macaca fasicularis. Endocrin$\operatorname{olog} y$ 92, 1296-1300.

Voller, A., Green, G.I. \& Richards, W.H.G. (1973) Cross immunity studies with East and West African strains of Plasmodium falciparum in owl monkeys (Aotus trivirgatus). J. Trop. Med. Hyg. 76, 135-139.

Wildt, D.E., Doyle, L.L., Stone, S.C. \& Harrison, R.M. (1977) Correlation of perineal swelling with serum ovarian hormone levels, vaginal cytology, and ovarian follicular development during the baboon reproductive cycle. Primates 18, 261-270. 
Wilson, M.I. (1977) Characterization of the oestrous cycle and mating season of squirrel monkeys from copulatory behavour. J. Reprod. Fert. 51, 57-63.
Wolf, R.C., O'Connor, R.F. \& Robinson, J.A. (1977) Cyclic changes in plasma progestins and estrogens in squirrel monkeys. Biol. Reprod. 17, 228-231.

Received 12 October 1978 